\title{
THE POSSIBILITY OF USING NANOFERTILIZERS TO RAISE THE EFFICIENCY OF VEGETABLE CROPS PRODUCTIVITY, IMPROVE THE QUALITY AND REDUCE THE DAMAGE OF BIOLOGICAL STRESSES \\ (REVIEW ARTICLE)
}

Fathel F. R. Ibraheem

Horticulture and landscape department, College of Agriculture and Forestry, Mosul University, IRAO.

Email: fathelffr@uomosul.edu.iq

\begin{abstract}
Several methods were used to increase productivity and quality of the product for vegetable crops and prolong their presence in the markets, including the treatment of various vegetable crops with industrial growth regulators and mineral fertilizers, whether fertilizers containing in their composition micronutrients or major nutrients. Global statistics have shown in many studies that there are large numbers of people in the world whose number exceeds 3 billion peoples who suffer from undernutrition, especially the shortage of micronutrients, as this problem can be overcome by adding fertilizers containing these elements to agricultural production fields in different ways, but the use of these chemical fertilizers may have negative harmful effects on the environment and public health in addition to the high prices, which constitute an economic burden on farms, so the researchers moved not long ago to adopt the idea of using nano-fertilizer to raise production efficiency and reduce the harm of biological stresses reduce the cost of production processes as well as it is the safest food source compared to chemical fertilizers in vegetable crops, which have been used and utilized in many scientific fields in many countries of the world.
\end{abstract}

Keywords: Nano; Nano-fertilizer; Biological stresses.

Received: 13/ 7/2020, Accepted: 22/ 9 /2020

\section{INTRODUCTION}

As a result of the possibility of growing vegetable crops in more than one growing season in many countries of the world, their cultivation may reach three growing seasons per year, this has led to an increase in the amount of mineral fertilizers added in the commercial production fields of vegetable crops compared to other crops such as fruit, which has hurt to exacerbate and increase the harmful effects of the environment (Abdel Wahab et al., 2017), and the general health of society, especially the residual effect of nitrates considered as the most dangerous to human health (Othman, 2007). Therefore it was obligatory for researchers in the agricultural field to think about finding alternative means of chemical fertilizers to ensure the reduction of environmental pollution and biological stresses to which microscopic soil organisms benefiting the plant are exposed as a result of excessive use of chemical fertilizers (Sara, 2006; Mahmoud et al., 2016; Hammad and Hussein, 2016; AL- 
Sheikh, 2017; Ibraheem, 2018; Ibraheem et al., 2019), and that the use of the newly introduced nano-system in agriculture is one of the revolutions scientific to achieve the highest production in vegetable crops at a lower cost, which can reduce some of the vital stresses that affect vegetable crops and the beneficial microorganisms of soil and plants (Siddiqui and Al-Whaibi, 2014; Manjunatha et al., 2016; Sarlak, 2017).

\section{What is the concept of nano?}

The word nano has been defined in the Greece language as a derivation from the word dwarf or the finite thing in infancy (Borisenko and Ossicini, 2005), while the word nano scientifically indicates that it is a material whose dimensions are one billionth of a meter per square meter (Anderson, 2015), as this unit It is used to measure the microscopic particles, atoms and minutes of complex materials (Heiz and Landman, 2007; Raab et al., 2011).

\section{The unique properties of nanoparticles to reduce the biological stresses that affect plants and soil:}

Depending on the concept of nanotechnology, given that particles with very small sizes are less than 1000 nanometers (Brunner et al., 2006), they provide materials that have in their composition essentially different features and behaviors than those of the larger minutes, the smaller of nanoscale size of a particle, the more of its atoms that make up its surface relative to the number of particles interring inside the body and this change between the ratio of the surface atoms to the internal atoms of the nanoparticles is what explains the change in the chemical and physical properties of the nanocomposites (Lee et al., 2008, 2010; Bajai, 2017), and one of the most important of these characteristics is the characteristic of hardness as the small size of nanoparticles the presence of huge numbers of atoms on their outer surfaces increases the hardness of materials and increases their resistance to vital stresses. The nanoparticles are also characterized by a few melting point that is less than many times larger than they are in the natural state (Bajai, 2017). Also, the nanoparticles have very high chemical activity as they are used to convert toxic and harmful gases into safe gases (Al-Mutairi, 2012), and this is thus reflected in reducing the vital stresses they are exposed to soil and plants. Nano fertilizers are characterized by their high solubility in addition to their high efficiency in penetrating plant tissues and used in small quantities and with high efficacy and thus play an important role to solve many of the problems that agriculture is exposed to including chemical inorganic fertilizer which sill a subject a subject of controversy about its negative effects on soil and plants due to its decomposition slow growth and increased accumulation in the soil, which increase the soil and plant stress (Monreal et al., 2016). The large surface area characteristic of nano-fertilizers is that it participates in increasing the activity of enzymes that are directed to increasing the speed of chemical and biological reactions of the plant cell, increasing the synthesis of amino acids and nucleic acids, as well as the role that nanomaterials play in inhibiting the formation of free radicals which appear when the plant is exposed to stress due to the lack of irrigation water and this leads to less oxidative processes and thus to encourage vegetative growth of the plant and delay aging (Morteza et al., 2013). 
Nano-materials can be used as carriers of insecticides and fungi to control insect and fungal diseases, which are considered vital enemies of vegetable plants, as nanoparticles contribute to the slow release of a chemical to a specific host to control pathogenic insects from a liberating mechanism that includes disintegration or biodegradation, diffusion, and osmotic pressure at a certain $\mathrm{pH}$ (El-Jawadry and Ali, 2019). In general, coated insecticides and fungicides have the ability to target a specific insect or fungus and thus the quantity of the added pesticide is less than the usual pesticide as the insecticide and nanoparticle absorbs on plant surfaces and is slowly released and for a longer period of time than the conventional pesticide that is lost by washing (Scrinis and Lyons, 2007). Tribolium castaneum insect could be eliminated by using nanoparticles loaded with garlic oil (Barik et al., 2008). Sarlak et al. (2014) observed that when encapsulating the mancozeb fungicide with multiple layers of carbon nanotubes inlaid with citric acid this process transformed the large fungicide into a nano fungicide and the effectiveness of this pesticide on the fungus alternativearia altemate was studied and the results confirmed that the nanocide was significantly superior to the pesticide the traditional inhibitory effect on the fungus. At the present time, there are many pesticides and fungicides in the form of nanoparticles, which are used in commercial production, which leads to reducing the quantities of pesticides used in the prevention of insect and fungi diseases that affect vegetable plants, as the intended matter was achieved in the fight against various pests in small quantities, given that it can be used on only affected plant parts, thus reducing environmental pollution and reducing the cost of the resistance process as a result of the use of nanocides (Barrena et al., 2009.; Kottegoda et al., 2011.; Elfeky et al., 2013).

Significant results to increasing yield and improving quality of many vegetable crops achieved through the use of nano-fertlizers:

One of the most important uses of nanotechnology is nano-fertlizers, which improves the ability of plants to absorb nutrients (Mousavi and Rezai, 2011; Srilatha, 2011; Ditta, 2012). Different nanoparticles for example silicon palladium, gold, and copper impact seed germination of lettuce Lactuca sativa (Belozerova, 2009).The use of nano-fertilizer $\mathrm{Zn}$ at a spray rate of $0.28 \mathrm{~g} \mathrm{~L}^{-1}$ significantly increased corn plant height, dry weight and improved product quality when compared to control plants (Adhikari, 2011). It was observed that the eggplant plants which nanostructures were added sprayed on vegetative growth at a concentration of 1 and $2 \mathrm{~g} \mathrm{~L}^{-1}$, that the height of the plant and the average number of branches and fruits increased significantly when using the concentration of $2 \mathrm{~g} \mathrm{~L}^{-1}$ compared to the control treatment (Bozorgi, 2012). The seedlings of Sitrullus lanatus and the dry weight of the root and vegetative population increased significantly when using nano-silver fertilizer at concentrations of $0.05-2.5 \mathrm{mg} \mathrm{L}^{-1}$ in the study conducted by (Almutairi and Alharbi, 2015). In the potato tubers production field an experiment was conducted by Mohsen et al. (2016) to compare the use of $\mathrm{N}_{20} \mathrm{P}_{20} \mathrm{~K}_{15}$ mineral fertilizer at a rate of $200 \mathrm{~kg} \mathrm{ha}^{-1}$ and potassium and zinc mixed with nanoparticles with chelated form at a rate of $1 \mathrm{~kg} \mathrm{ha}^{-1}$, the results 
of this study showed that there are significant differences between chemical and nanofertilizers in all studied vegetative characteristics and yield, which indicates the efficient use of nano-fertilizers in these fields due to the small amount of fertilizers used compared to chemical fertilizers. The significantly effect of nano $\mathrm{ZnO}$ has been reported in crops like onion (Allium cepa L.), green pea (Pisum sativum L.) and spinach (Spinacia oleracea) (Laware and Raskar, 2014; Mukherjee et al., 2016; Singh and Kumar, 2016). Ezzat and Mohammad (2016) reported that the hardness of tomato plant fruits, soluble solids, and fruit content of vitamin $\mathrm{C}$ when fertilizing with calcium, iron, and zinc nanoparticles increased significantly. Bajai (2017) achieved a significant effect on carrot plant height, number of leaves, total chlorophyll content, root length, nitrogen, protein and iron concentrations, and $\beta$-carotene content in the root when using nano-silver fertilizer at a concentration of $15 \mathrm{ml} \mathrm{L}^{-1}$ versus increased potassium and zinc at a concentration of $30 \mathrm{ml} \mathrm{L}^{-1}$, phosphorus and calcium at a concentration of $45 \mathrm{ml} \mathrm{L}^{-1}$. Red cabbage and broccoli plants are among the plants of the Brassicaceae family, which are very important in terms of indicative health, as it is possible to reduce the incidence of many cancerous diseases by eating these crops in the authorities or cooked, so some studies focused on increasing productivity and improving the quality of these crops. Ahmed and et al. (2018) studied the effect of adding nano-fertilizer, organic and mineral fertilizers in the red cabbage and broccoli plants, as the results of this study showed that the use of nanoparticle fertilizer and nano-selenium with organic fertilizers gave the best significantly results in the growth and yield characteristics studied in this plants compared with the use of chemical fertilizers. Nano particles can enter the plants leaves through the stomata and transported to the different organs (Singh et al., 2017; Qureshi et al., 2018; Al-juthery et al., 2018; Al-juthery and Saadoun, 2018). Study Ahmed et al. (2019) to explain the physiological role of nano-fertilizers on summer squash plant, the study included the use of three types of nano-fertilizer $\left(\mathrm{Fe}_{2} \mathrm{O}_{4}, \mathrm{Mn}_{3} \mathrm{O}_{4}\right.$ and $\mathrm{ZnO}$ nano-fertilizer) individually for each fertilizer in addition to the use of these fertilizers in a joint combination of each fertilizer and combination, the three types of these fertilizers included a concentration of $20 \mathrm{ml} \mathrm{L}^{-1}$, the study continued for two years. results of this study showed that the use of all these fertilizers individually and in a double form between each fertilizer has led to a significant increase in all studied vegetative growth characteristics represented by plant height, number of leaves and leafy area of plant and the fresh and dry weight of the plant in addition to improving the qualitative yield characteristics related to the length and diameter of the fruit and the yield of the plant in addition to the qualitative characteristics of the fruits that included increasing the ratio of protein, oils, carbohydrates and fibers. Al-Khafaji (2019) connected that the use of a combination of nano-fertilizers containing the major elements NPK, microelements $\mathrm{Co}, \mathrm{Mn}, \mathrm{Fe}, \mathrm{Zn}, \mathrm{Mo}, \mathrm{B}$ and compound fertilizer $\mathrm{N}_{15} \mathrm{P}_{15} \mathrm{~K}_{15}$, this combination achieved significant superiority in the characteristics of vegetative growth, yield and quality, as each number of stems increased the height of the plant, number of leaves, percentage of chlorophyll in the leaves, leafy area, percentage of dry 
matter in the vegetative total, number of marketable tubers, marketable yield, percentage of dry matter in the tubers, percentage of starch, protein, nitrogen and phosphorus in the tubers of potato plants. Researcher Ahmed (2019) reached a significant increase in root length, plant height, leafy area, leafy area index, increase in the ratio of free water to restricted water, stem content of chlorophyll a and chlorophyll b, in sweet pepper plant fruits of total carbohydrates, total sugars, nitrogen, potassium, and phosphorus in addition to the increase significance in fruit yields when spraying plants with Lithovit nano-fertilizer, which contains in its composition calcium, nitrogen, phosphate, potassium, magnesium and selenium in the nanostructure form, as this fertilizer was used in a concentration of 2.5 and $5 \mathrm{~g} \mathrm{~L}^{-1}$. Different concentrations (3, 4.5, 6 and $9 \mathrm{ml})$ of liquid nano NPK were used. The results showed that the nanofertilizer treatments significantly improved the growth and yield of cucumber compared with control treatment. All treatments of nano-fertilizer led to increase plant height, number of leaves plant ${ }^{-1}$, Chlorophyll content, yield and NPK \% in leaves and fruits (Merghany et al., 2019). Suler-nano fertilizer at $200 \mathrm{mg} \mathrm{L}^{-1}$ concentration and zing-nano fertilizer at $50 \mathrm{mg} \mathrm{L}^{-1}$ caused significant effect on height branch number of broad bean plants (Kahlel et al., 2020). Study of Ghidan et al. (2020) to explain the physiological role of nano-fertilizers on the yield and $\mathrm{N}$ ion contain of broad bean plants, the study included the use of two types of nan-fertilizers (Zinc at $50 \mathrm{mg} \mathrm{L}^{-1}$ and Sulfer at $200 \mathrm{mg} \mathrm{L}^{-1}$ concentration) results of this study showed that the use two fertilizers and led to a significant increase in most yield studied increasing the ratio of $\mathrm{N}$ ion in the seeds.

\section{Based on the above, this article can be connected with a number of important conclusions.}

1- The use of fertilizers with nanostructures may help us reduce soil and water pollution problems.

2- Reducing the use of chemical fertilizers, which reduces the residual effect of chemical fertilizers, which may lead to climatic changes that are inappropriate for humans and plants.

3- The quantities of nano-fertilizer used in agriculture are very small when compared to chemical fertilizers, which leads to an increase in the economic yield and a reduction in the problems of soil and air pollution.

4- The use of pesticides and fungi in the nanostructure reduces the quantities of pesticides used in the control and thus reduces vital stresses.

5- Improving the characteristics of the vegetative growth of many vegetable crops that were enriched with nano-fertilizer.

6- Improving the quality of vegetable products by increasing the percentage of nutrients in vegetable plants that have been treated with nanostructures.

The aforementioned about the properties of nano-fertilizers and their role in reducing vital stresses and increasing the productive yield in vegetable crops and useful conclusions from the use of nano-fertilizers for humans, plants and the agricultural environment this does not mean that there are no side risks from the use of nano- 
fertilizers on it we recommend in this article to conduct future research specializing in the side effects that nano-fertilizers may cause it to the general health of society.

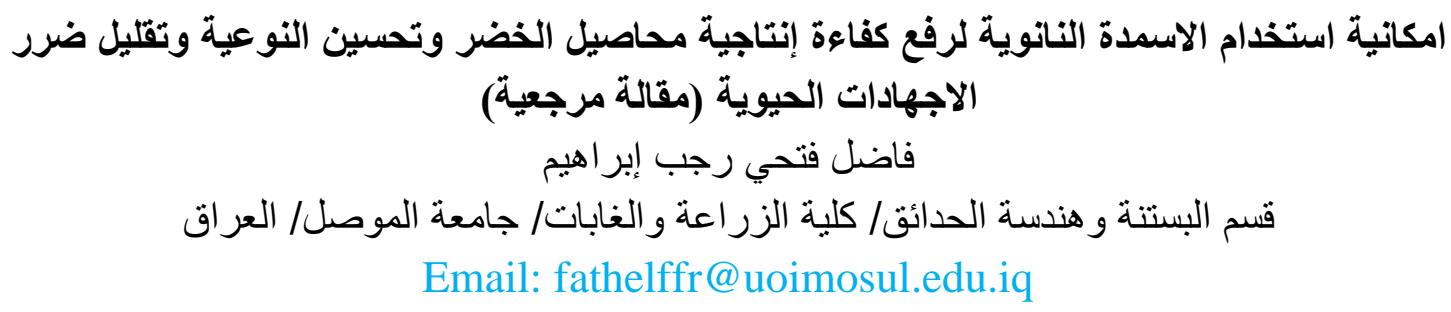

\section{الخلاصة}

استعلت عدة طرق لزيادة الإنتاجية ونوعية المنتج لمحاصيل الخضر واطالة فترة تواجدها في الأسواق منها معاملة مختلف محاصيل الخضر بمنضمات النمو الصناعية والاسمدة المعدنية سواء كانت اسمدة تحتوي في تركيبها على مغذيات صغرى او كبرى. وقد دلت الإحصاءات العالمية في دراسات عديدة ان هناك اعداد كبيرة من

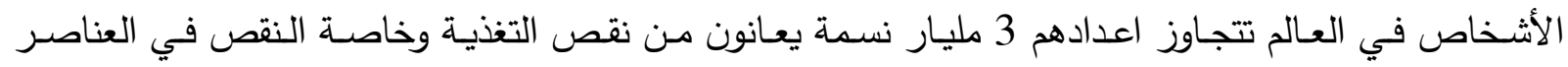

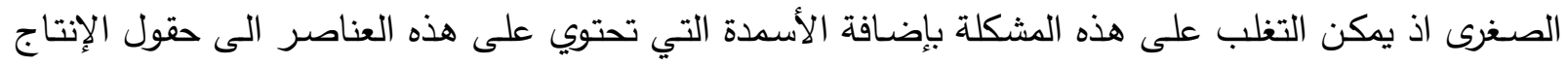

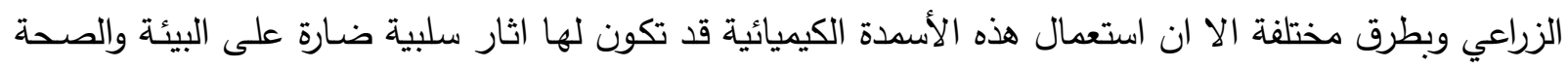

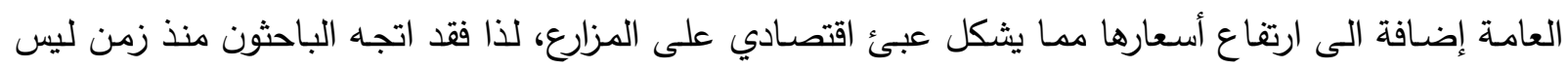

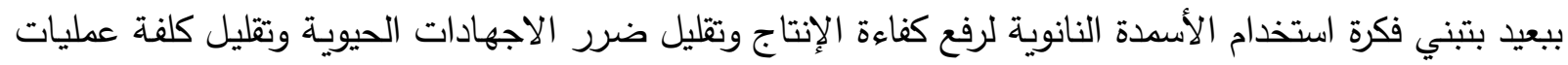

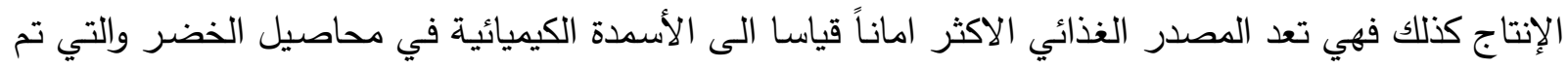

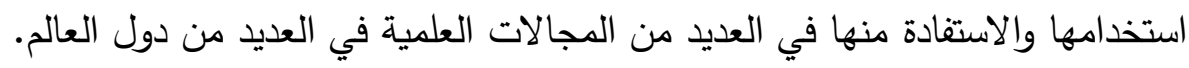
الكلمات الادالة: نانو . سماد نانوي. اجهادات حيوية.

$$
\text { تاريخ تسلم البحث:2020/7/13، وقبوله:2020/9/22 }
$$

\section{REFERENCES}

Abdel Wahab, .M.M., El-attar A.B. and Mahmoud A.A. (2017). Economic evaluation of nano and organic fertilizers as an alternative source to chemical fertilizers on Carum carvi L. plant yield and components. Agriculture (Polnohospodárstvo), 63(1): 33-49.

Adhikari, T. (2011). Nano-particle research in soil science micronutrients. In: Proceedings of the national symposium on 'application of clay science: agriculture, environment and industry'. 18-10 February 2011, NBSS \& LUP, Nagpur, pp. 74-75. 
Ahmed, M.A. (2019). Nano-fertilizer application to increase growth and yield of Sweet Pepper under potassium levels. Agri. Res. and Tech., 19(4):145-157.

Ahmed, S., Hassan A.A., Dina M., Salama E., A. El-Aziz and Abd Elwahed S.A. (2019). Green synthesis of nanofertilizers and their application as a foliar for Cucurbita pepo L. Journal of Nanomaterials, 4: 1-11.

Ali, N.S.H. and El-Jawadry H.O.A. (2019). Nanoscience in soil and plant system. .Republic of Iraq. AL-Thaqalain press.

Al-juthery, H.W.A. and Saadoun S.F. (2018). Impact of foliar application of micronutrients nanofertilizers on growth and yield of Jerusalem artichoke. Iraqi Journal of Agricultural Sciences, 49(4):577-585.

Al-juthery, H.W.A., Ali N.S., Al-taee D. and Ali E.A.H.M. (2018). The impact of foliar application of nanoferilizer, seaweed and hypertonic on yield of potato. Plant Archevs, 18(2): 2212 -2207.

Al-Khafaji, A.K.A. (2019). Response of potato (Solanum tuberosum L.) to nano fertilizer and planting dates on growth and yield of autumn grown plants. M.Sc. Thesis, Agriculture College, Department of Horticulture, AL-Qasim Green University, Iraq Republic.

Al-Mutairi, T.B.M. (2012). Role of nanotechnology in disaster reduction. Publication of International Islamic University. Malaysia.

Almutairi, Z.M. and Alharbi A. (2015). Effect of silver nano particles on seed germination of crop plants. Int. J. Bio. Agric. Biotech. Eng., 9(6): 572-576.

Alsheikh, M.A.A. (2017). Effect of planting dates, organic, chemical fertilizer and humic acid on vegetative growth, quantity and quality of yield of table beet. M.Sc. Thesis, Collage of Agriculture and Forestry, Mosul University, Ministry of Higher Education and Scientific Research.

Anderson, A.J. (2015). Nano-CuO and interaction with nano-ZnO or soil bacterium provide evidence for the interference of nanoparticles in metal nutrition of plants. Ecotoxicology, 24:119-129.

Bajai, H.S. (2017). Effect nano silver, magnetized water and compound fertilizer on growth and active substances production of carrot plant Daucus carota L. M.Sc. Thesis, Education College, Department of Biology, AL-Qadisiyah University, Iraq Republic.

Barik, T.K., Swan B. and Dawood S.M. (2008). Nano silica from medicine to pest control. Paracetol Res., 103: 253-258.

Barrena, R., Casals E., Colon J., Font X., Sanchez A. and Puntes V. (2009). Evaluation of the eco toxicity of model nanoparticles. Chemosphere, 75: 850-857.

Belozerova, I. (2009). Influence of metal nanoparticles on the soil microbial community and germination of lettuce seeds. Water, Air, and Soil Pollution. 197(1-4): 143-148.

Borisenko, E. and Ossicini S. (2005). What is What in the Nano world: A Handbook on Nanoscience and Nanotechnology. Weinheim: Wiley-VCH, BA . 
Bozorgi, H.R. (2012). Study effect of nitrogen fertilizer management under nanoiron chelate foliar spraying on yield and yield components off eggplant (Solanum melongena L.). J.Agric and Biol.Sci., 7(4): 233-237.

Brunner, T.J., Wick P., Manser P., Spohn P., Grass R.N., Limbach L.K., Bruinink A. and Stark W.J. (2006). In vitro cytotoxicity of oxide nano-particles: Comparison to asbestos, silica, and effects of particle solubility. Environ. Sci. Technol., 40:4374-4381.

Ditta, A. (2012). How helpful is nanotechnology in agriculture? Advances in Natural Sciences: Nanoscience and Nanotechnology, 3: 10.

Elfeky, S.A., Mohammed M.A., Khater M.S., Osman Y.A.H. and Elsherbini E. (2013): Effect of magnetite nano-fertilizer on growth and yield of Ocimum basilicum L. International Journal of Indigenous Medical Plant, 46: 1286-1292.

El-Henawy, A., El-Sheikh I., Hassan A., Madein A. and Salah E.D. (2018). Response of cultivated Broccoli and Red Cabbage crops to mineral, organic and nanofertilizers .Env. Biodiv. Soil Security, 2: $221-231$.

Ezzat, K. and Mohammad R. (2016). The effect of methanol foliar spray and some of nano-fertilizers on tomato fruit quality and quantity. Transylvanian Journal, 24(11).

Ghidan, A.Y., Kahlel A.M.S. and Al-Antary T.M. (2020). Effects of nanotechnology liquid fertilizers on yield and nitrogenous compound of broad bean (Vicia faba L.). Fresenius Environmental Bulletin, 29(6): 4383-4788.

Hammad, K.H. and Hussein H. A. (2016). Effect of NPK and chicken manure on the productivity and some growth components of squash (Cucurbita pepo L.). Journal of Agricultural and Biological Science., 11(6): 230-235.

Heiz, U. and Landman U. (2007). Nanocatalysis. Nanoscience and Technology. Berlin: Springer.

Ibraheem, F..F.R, Allela W.B.A.M. and AL-Bayati H.J.M. (2019). Effect of soil mulching, organic and inorganic fertilizer on growth and yield of summer squash. Int. J. Agricult. Stat. Sci., 15(2): 677-685.

Ibraheem, F..F.R. (2018). Response of tow potato cultivars to humic acid fertilizer. Mesopotamia J. of Agric., 43(2): 18-28 .

Kahlel, A.M.S., Ghidan A.Y. and Al-Antary T.M. (2020). Effects of nanotechnology liquid fertilizers on certain vegetative growth of broad bean (Vicia faba L.). Fresenius Environmental Bulletin, 15(2): 4763-4768.

Kottegoda, N., Munaweera I., Madusanka M. and Karunaratne V. (2011): A green slow release fertilizer composition based on urea-modified hydroxyapatite nanoparticles encapsulated wood. Current Science, 101(1): 73-78.

Laware, S.L and Raskar S. (2014). Influence of zinc oxide nanoparticles on growth, flowering and seed productivity in onion. Int. J. Curr. Microbiol. App. Sci., 3: 874-881. 
Lee, W.L., Mahendra S., Zodrow K., Li D., Tsai Y.C., Braam J. and Alvarez P.J.J. (2010). Developmental phytotoxicity of metal oxide nanoparticles to Arabidopsis thaliana. Environmental Toxicology Chemistry 29: 669-675.

Lee, W.M.; Yoon Y.J. and Kweon H. (2008). Toxicity and bioavailability of copper nanoparticles to the terrestrial plants mung bean (Phaseolus radiatus) and wheat (Triticum aestivum): plant agar test for water-insoluble nanoparticles. Environmental Toxicology Chemistry, 27: 1915-1921.

Mahmoud, E., Abd EL- Kader N., Robin P., Akkal-Corfini N. and Abd El-Rahman L. (2016). Effects of different organic and inorganic fertilizers on cucumber yield and some soil properties. World Journal of Agricultural Sciences, 5(4): 408414.

Manjunatha, S.B., Biradar D.P. and Aladakatti Y.R. (2016). Nanotechnology and its applications in agriculture: A review. J. Farm Sci., 29(1): 1-13.

Merghany, M.M., Shahen M.M., Sllem M.A.S. and Abdelgawad K.F. (2019). Effect of nano-fertilizers on cucumber plant growth, fruit yield and it is quality. Plant Archives, 2(19): 165-172.

Mohsen., N., Janmohammadi P., Abdollah J. and Naser S. (2016). Effects of bioorganic, conventional and nano fertilizer on growth, yield and quality of potato in cold steppe. Botanical Lithuanica, 22(2): 133-144.

Monreal, C.M., Derosa M., Mallubhotla S.C., Bindraban P.S. and Dimkpa C. (2016). Nanotechnologies for increasing the crop use efficiency of fertilizermicronutrients. Australia. Biology and Fertility of Soils, 52(3): 423-437.

Morteza, E., Moaveni P., Farhane P. and Mortez M. (2013). Study of photosynthetic pigments changes of maize under nano $\mathrm{TiO}_{2}$ spraying at various growth stage. Springer Plus, 2(247): 1-5.

Mousavi, S.R. and Rezaei M. (2011). Nanotechnology in agriculture and food production. Journal of Applied Environmental and Biological Sciences 1(10): 414-419.

Mukherjee, A., Sun Y., Morelius E., Tamez C. and Gardea-Torresdey J.L. (2016). Differential toxicity of bare and hybrid $\mathrm{ZnO}$ nanoparticles in green pea (Pisum sativum L.): A life cycle study. Front Plant Sci., 6: 1242.

Othman, J.Y. (2007). Study the effect of using organic fertilizers in cultivating and producing potatoes as a contribution in increasing clean organic production. M.Sc. Thesis, Agricultural College, Department of Horticulture, Tishreen University, Lathikia, Syrian Arab Republic.

Qureshi, A., Singh D.K. and Dwivedi S. (2018). Nano-fertilizers: a novel way for enhancing nutrient use efficiency and crop productivity. Int. J. Curr. Microbiol. App. Sci., 7(2): 3325-3335.

Raab, C., Simko M., Fiedeler U., Nentwich M. and Gazso A. (2011). What are synthetic nanoparticles. Nano Trust- Dossier and Plant production. 4(1): 6468. 
Sara, M.K.L. (2006). Squash (Cucurbita pepo L.) growth and yield in response to different types of fertilizers. M.Sc. Thesis, Agricultural Science, University of Khartoum.

Sarlak, N., Taherifar A. and Salehi A. (2014). Synthesis of nano-pesticides by encapsulating pesticide nanoparticles using functionalized carbon nanotubes and application of new nanocomposite for plant disease treatment. J. Agric. Food Chem., 62: 4833-4838.

Sarlak, N.A. (2017). Encapsulation of Nanomaterials and Production of Nanofertilizers and Nanopesticides: Insecticides for Agri-food Production and Plant Disease Treatment. In: Ghorbanpour M., Manika K. and Varma A. (Eds.). Nanoscience and Plant-Soil Systems. DOI: 10.1007/978-3-319-46835-8_18, pp: 481-498. Springer International Publishing AG.

Scrinis, G. and Lyons K. (2007). The emerging nano-corporate parading: nanotechnology and the transformation of nature, food and agri-food system. Int. J. Social Food Agric., 7: 31-53.

Siddiqui, M.H. and Al-Whaibi M.H. (2014). Role of nano-SiO 2 in germination of tomato (Lycopersicum esculentum seeds Mill.). Saudi Journal of Biological Science, 21: 13-17.

Singh, D. and Kumar A. 2016). Impact of irrigation using water containing $\mathrm{CuO}$ and $\mathrm{ZnO}$ nanoparticles on Spinacia oleracea grown in soil media. Bull. Environ. Contam. Toxicol., 97: 548-553.

Singh, M.D., Gautam C., Patidar O.P., Meena H.M., Prakasha G. and Ishwajith V. (2017). Nano- Fertilizers is a new way to increase nutrients use efficiency in crop production. international journal of agriculture. International Journal of Agriculture Sciences, 9(7):3831- 3833.

Srilatha B. (2011). Nanotechnology in agriculture. Journal of Nanomed. Nanotechnol., 2: $5-7$. 